\title{
THE FIRST SLOVAK-AMERICAN FRATERNAL ORGANIZATIONS AND PRESS
}

The aim of this work is to point out the characteristic features of the selected Slovak American fraternal organizations and Slovak press in the USA as the symbols of the raise of Slovak patriotism and the preservation of the Slovak cultural heritage. It provides the historical and political background of Slovak American immigration, settlement in the USA as well as the first political and fraternal activities that encouraged the Slovak nation to speak up for their rights and helped to awaken the Slovak interest in national issues, solidarity and a high sense of Slovak identity.

Key words: Slovak American immigrants, fraternal organizations, immigration, press

\section{Introduction}

The immigration, as social and demographic phenomena, has played an inherent part of the Slovak history over the centuries. The grounds for the immigration were usually marked by poor social, religious and economic conditions in Austrian-Hungarian Empire. Nowadays most Slovak Americans are descendants of immigrants who came to the US between the years 1865-1914.

We can recognize three main streams of Slovak immigration into the USA. The first stream dates back to late 1870s due to social, economic and educational reasons and due to the promise of prosperity, so called American dream. The second wave of immigration hit the USA between the years 1918-1938. Many immigrants took up the hardest jobs in coal mines or steel industry. Soon, America imposed the law to stop a large wave of immigration into the USA by setting a discriminatory immigration quota system which resulted in the larger immigration into Canada [1]. The take-over of Czechoslovakia by communists and Soviet Union's invasion purred another wave of immigration for political reasons. Most of immigrants were members of intelligentsia and post war figures who had to avoid a political persecution.

The main source of living for most Slovaks in the $19^{\text {th }}$ century was agriculture. Many of them were day workers or small farmers who owned no land. Slovaks were poor peasants with poor education due to strong Hungarian efforts for language assimilation of other nations in Austro-Hungarian Empire. In the middle of the $19^{\text {th }}$ century, Slovaks were accustomed to migrate to the nearby part of Austro-Hungarian Empire. When there was no other possibility to migrate in surrounding areas, they were forced to flee into America or Canada where the immigration was supported by the government due to heavy industrialization of the country. The most common areas of the settlement were New York, Pennsylvania, Ohio, Illinois, Connecticut, Florida, Iowa, Kansas and California. Most of these settlements represented the most industrialized parts of the USA with the high concentration of steel, coal and mine industries. The American employers were aware of the fact that Slovaks would not leave their job unless they earned enough money to return back home to Europe so the immigrant's wages were kept were low but still higher than in Austrian-Hungarian Empire.

The new life in America had brought the significant change in social, cultural and political activities of Slovak immigrants. From the underestimated people they developed to the nation aware of their national roots and linked together by their mutual needs and patriotism liberalized from the Hungarian oppression mostly in years 1848-1918. Soon after their arrival, the immigrants had understood their need for organizing for both protection and support in a foreign country. The Slovak priests became their religious, social and national leaders.

This article aims to provide the highlights of first political and national activities of Slovak immigrants in the USA. The Slovak fraternal organizations were created with intention to preserve Slovak and Czech culture, history, traditions as well as to help their members to adapt to American way of life. What is more they paved the path for the first Slovak press activities both in America and back home in Europe.

\section{The first Slovak fraternal Organizations and their Political Activities}

The Catholic religious traditions kept the Slovak immigrants together and supported their intentions to gather for both their

\footnotetext{
* Michaela Bakay Zahorska

Institute of Foreign Languages, Faculty of Humanities, University of Zilina, Slovakia, E-mail: zahorskamichaela@yahoo.com
} 
protection and support. Many of them left their families and felt lonely. Soon, they started to group together and formed several organizations and societies of political, social cultural and economic benefits for their community. The fraternal benefit organizations were therefore founded and led mostly by the church leaders.

In the first years of Slovak settlement in the USA, various kinds of problems were discussed in so called "saloons" where beer and cheap meals were served. Slovak immigrants felt the need for social services and formal communities. Soon, the first formal institutions were established in the USA called the fraternal-benefit societies.This organizations represented a radical change in thinking and acting of Slovaks in America and they sow the seeds for interfering into political situation in their home land in Europe later on during the years of the formation of the first Czecho-Slovak Republic.

First organizations were established on the religious basis. Roman Catholic, Greek Catholic, Lutherans and etc set up their own institutions sometimes within the same community. Commonly, they helped to establish the community churches [2]. The national and social programs represented a high priority for Slovak-American fraternal organizations with the intention to build national awareness in Slovak immigrants. Soon, more than 40 fraternal organizations had been formed in northeastern and midwestern United States. One of their primary goals was the unification of all organizations on a nationwide basis. In addition, they provided supplementary lessons especially for children of Slovak origin in Saturday or afternoon schools and provided the immigrants and their families with disability insurance and death benefits. For instance, when a worker was injured, the association compensated their family. They helped the immigrants to adjust to American way of living. Many priests had left Austrian-Hungarian Empire and settled the parishes in the USA. Peter V. Rovnianek was the first leader of this movement. First organizations were built near Slovak immigrant settlements but as a result of the migration their offices moved to other parts of the country. The foundation of the fraternal associations represented the significant shift of Slovak life from humiliation to democracy and liberty [3].

The First Catholic Slovak Union of the USA and Canada was founded in February 1890 by Rev. Stephen Furdek followed by The First Catholic Slovak Ladies Association of the USA and Canada in 1892 and The Slovak Catholic Sokol in 1905. The National Slovak Society was formed in Pittsburgh by Peter V. Rovnianek, the man who launched the first Slovak daily newspaper in Pittsburgh and who dreamt of uniting all Slovaks under one association. But Stefan Furdek, a reverend of Cleveland, established a rival organization called the First Catholic Slovak Union of the United States and later of Canada on September 4, 1890.

Peter Rovnianek was a significant personality in Slovak American movement and he helped to scatter small local lodges into organizations acting on a national basis. He dreamt of a national fraternal organization and fought against the oppression of Slovaks in Hungary. He was one of the greatest leaders of Slovak American community. He studied in Budapest and became a prominent journalist and a founder of the National Slovak Society on February
25,1890 . However soon he had to face the opposition of Stefan Furdek who showed his disagreement of the nondenominational national fraternal. Furdek supported the guidance of Roman Catholic priests in Slovak National Society.

The national Slovak Society, the Slovak League of America, was founded in 1907 to help to prepare Slovak immigrants for American citizenship and to promote the welfare of Slovaks in the USA. Their members organized donations for funerals or provided the support for the political movements back home [3]. The formation of the Slovak League of America meant a breakthrough in the life of Slovak immigrants as well as back home in Europe. Slovak League of America in combined effort with other ethnic organizations helped the immigrants to become US citizens and to promote their Slovak national heritage in order not to be considered as Austrians or Hungarians. T.G. Masaryk asked The Slovak League of America together with the Bohemian National Alliance, the Czech organization in the USA, to support the activities towards the formation of the first common state of Czechs and Slovaks. In 1914 T.G. Masaryk started the movement of liberalization of the Czechs and Slovaks from Austrian and Hungarian rule. T.G. Masaryk considered Slovaks and Czechs to be one nation and supported the idea of the common independent state. But the Slovak League was not sure about the idea of a new common state due to the fact the Czechs outnumbered the Slovaks in Europe and did not want Slovaks to be dominated by the Czechs. Eventually, the representatives insisted on the common state on the federation basis. The Cleveland Agreement was signed on 22 October, 1915 followed by the Pittsburgh Agreement on May 31, 1918 declaring an independent administration, courts, legislative, parliament, the use of their language for Slovakia within the common state named Czecho-Slovakia. It was the sign that Slovak Americans were able to support and control not just their own activities in the USA but more importantly back home in Europe that helped to form the Slovak patriotism and national identity [4]. The new state, CzechoSlovakia, was established on October 28, 1918 with the full competence of Slovakia to rule their part of the country.

The Slovaks received their own rights for ruling in 1938 at the time when Hitler rose his power.Czech authorities were aware of Hitler's ambitions to misuse the tension between Czechs and Slovaks to dismember Czechoslovakia and gave Slovakia the competence for self-ruling again. Hitler continued in his actions to dismember the common state and supported the idea of the Slovak declaration of independence. Soon, on March 14, 1939 the independence of Slovakia was proclaimed and the First Slovak Republic was created. The Slovak declaration of independence surprised Slovak immigrants but eventually they supported the new state. The Slovak League of America supported the new state until the United States was drawn into the war in 1941. Slovak Americans believed in the right of Slovaks to self-determination during the World War II. The Slovak League of America sent a delegation to the World Security Conference in San Francisco in 1945 to support the idea of the independent Slovakia. The discontent with the post war situation resulted in the next waves of immigration into the USA and Canada. The immigrants were mostly the supporters of the independent Slovak Republic [4]. 
Another wave of immigration of mostly official and intellectuals, the supporters or either Czechoslovakia or independent Slovakia, happened after the Communists seized the government. They both formed their own organizations and published their own newspaper. The Masaryk Club of Boston was named after the first president of Czechoslovakia Tomas Garrique Masaryk and supported the restoration of freedom in Czechoslovakia. The roots of the club date back to 1905, during the time when most of the Slovak and Czech immigrants arrived in South Boston. Many refugees from communist totalitarian system fled to America. The members of the club supported the American Fund for Czechoslovak refugees and continued with their social and cultural activities. In 1968 many intellectual dissidents had to leave Europe and came to the USA and Canada to seek liberty and a better life. They usually did not join already existed organizations. Another wave of immigration, about 3,000 people, appeared in 1970 and 1990.

\section{The first Slovak Press Activities in America}

It was the press that ensured the unified Slovak movement abroad. Apart from the lack of finances, many newspaper and magazine printing houses appeared very soon. Many of them were of no cultural or social value and stopped their activities very early. But overall, the newspaper or magazine represented the highest national institution for cultural and political life of Slovak immigrants and they fulfilled the information, scientific, educational, cultural and political functions that were lacking in Slovakia that time. It concentrated not just on the life in America but also in Europe. It was much easier for the first independent journalists or fraternal societies to write in a democratic environment than under the strict Hungarian pressure back home. Konstantin Culen in his study "Slovaks in America" divided the Slovak press in America into three major groups:

The first group was represented by Slovak press written to support Slovak nationalism, the second one the press written in Slovak language but not supporting Slovak national and cultural life and the third one was Hungarian and anti- Slovak oriented [5]. Many Slovak magazines and newspaper tried to meet the immigrant's needs for information. One of the first Slovak publishers was Peter Rovnianek and Stefan Furdek. They were rivals but both used their editorial skills to support Slovak nationalism among their readers because they belonged to the opposite religions divisions within the Slovak community in the USA. They attacked the Hungarian government in their articles [5].

The First Slovak press was formed under the social pressure and desire for relevant information. Its establishment was difficult because just few Slovak Americans were capable of reading and writing and due to the Slovak negative attitude to press in general. As K. Culen wrote in his study Slovak immigrants believed that the press belongs just to the hands of higher class. The first Slovak Bulletin was released in in 1885 by Jan Slovensky. Bulletin was not actually a real serious magazine but just the regular correspondence issued in the form of frateral letters informing Slovak Amer- icans about the everyday news. The bulletin was prescribed just by the owners of so called sallons and there it was read by almost the whole village [5].

First real printed Slovak newspaper issued in America was called Amerikansyko Szlovenszke Novini in Pitsburgh in 1886. One of the first authors of the newspapers' articles were Jan Slovensky and Jan Wolf. Another significant newspaper issued in America appeared in 1888 with the financial support of the Roman Catholic priest rev. Gelhoff. The magazine was called Nova vlast. Unfortunately, the magazine finished the same year it was established. Peter Rovnianek launched the first Slovak American newspaper written in official Slovak language. In 1891 Americansko slovenske noviny was founded and the newspaper became one of the most widespread newspapers in the region. Many authors living in Slovakia contributed with their articles into the newspaper critizing the Hungarian press issued in America as well as back home in Europe. Slovak in America is one of the oldiest Slovak newspapers issued in America. It was launched in 1889 in Plymounth as a weekly magazine [3]. The first Slovak English dictionary was published by Jan Slovensky and it was called Americky tlumac and was written in eastern dialect. It became very popular because it fullfilled all the needs of Slovak immigrants in America. In 1901 Peter V. Rovnianek launched Slovensky dennik as the first Slovak daily newspaper in America.

The peak of Slovak press was in 1936. During this time fiftyone newspapers appeared in Slovak language. Nowadays just one Slovak newspaper, the monthly Slovak in America is still published in Slovak language [5]. Besides the newspapers and periodicals, the immigrants enjoyed reading almanacs. The first one was published in 1890 and it was called Americky Slovak, the other one was named First National Almanach (Narodny Kalendar) which provided the index of 40 books published in America. Thanks to Slovak press in America, the social and political situation in Europe was well known throughout the world.

\section{Conclusion}

The fraternal organizations helped to form the national, cultural and religious identity of the Slovak immigrants. It helped to awaken the Slovak interest in national issues and encouraged the nation to speak up for their rights abroad as well as back in their home land. This paper stresses the significant change in development of Slovak national thinking within political, historical and cultural context with the help of the first political and cultural organizations and the first Slovak-American press release. Nowadays the descendants of Slovak origin are pround of their ancestor artistic, literary, technological, scientific and political activities and achievements. Many of them keep in touch with a contemporary situation in Slovakia by regular correspondence and visits to Slovakia as well as by subsribing the Slovak periodicals. Even nowadays the history of Slovak political activities in the USA continue to help to define the Slovak ethnicity in America and also in Europe. 


\section{References}

[1] STASKO, J.: Slovaks in the United States of America, Canada: Dobra kniha, 1974.

[2] BIELIK, F., SIRACKY, J.: Slovaks Abroad and National Cultural Heritage, In: Proc. of the Seminar on the 120. Anniversary of Matica Slovenska, Martin: MS, 1984.

[3] MOYNIHAN, D. P.: The Slovak Americans, New York : Chelsey House Publishers, 1988.

[4] STOLARIK, M. M.: Slovaks in Canada and the United States, 1870-1990: Similarities and Difference, Ottawa : The University fo Ottawa, 1992.

[5] CULEN, K.: Slovaks in America, Martin : MS, 1938. 